\title{
Saint Lucia-Mexico, Bilateral Relations
}

The development of strong, healthy and authentic global relationships has always been the core mandate of the Government of Saint Lucia since it attained its independence in 1979. This is reflected in Saint Lucia's membership in international groupings such as the United Nations, as well as regional blocs, such as the Caribbean Community (CARICOM), Community of Latin America and Caribbean States (CELAC) and the Organization of American States (OAS). These organisations demonstrate a commitment to advance the process of development and integration, with a focus on political, social and economic growth and stability.

While membership in international organisations such as the United Nations is important, especially as it provides legitimacy to a country's statehood, the equal importance of regionalism also needs to be highlighted. Saint Lucia's membership in the various regional organisations is indicative of the importance that it places on regional collaboration and integration. It is in this vein that Saint Lucia and Mexico have had a long standing and enduring relationship, which dates back to Saint Lucia's independence on $22^{\text {nd }}$ February 1979, when a delegation, representing the Government of Mexico visited Saint Lucia to witness this most auspicious event. Subsequently, Saint Lucia established diplomatic ties with the Government of Mexico on $17^{\text {th }}$ May 1979.

\section{Establishment of Embassy of Mexico in Saint Lucia}

The Government of Saint Lucia continues to pursue a greater level of bilateral interaction with Mexico. The relations which are shared between the two countries have materialised with the establishment of an Embassy of Mexico in Saint Lucia in 2005. This augurs well for the further deepening of co-operation for development. 


\section{Expansion of Bilateral Cooperation}

In 2011, the Government of Mexico and Saint Lucia signed a Tax Information Exchange Agreement as well as Double Taxation Agreement. In this current era of globalisation, which facilitates the rapid spread of commerce, people and information worldwide, taxation practices are a main factor. The Agreement between Mexico and Saint Lucia has established a framework to help foster and encourage movement of people and commerce between the two countries

Further with the establishment of the Mexican Agency for International Development Cooperation (AMEXCID) in 2011, the government of Mexico has expressed a keen desire to strengthen its assistance and involvement in the Caribbean region. Saint Lucia has consequently benefitted from such a commitment.

In June 2014, Saint Lucia and Mexico entered into two bilateral agreements which aim to insert a greater Mexican presence in Saint Lucia's national development efforts. The Agreements are as follows:

- Cooperation Agreement in the fields of Education, Culture, Youth, Physical Culture and Sports

- Basic Agreement on Technical and Scientific Cooperation between the United Mexican States and Saint Lucia.

- Under these agreements Saint Lucia has benefited in the areas of commercial and industrial development sector, education, diplomacy, culture, health, natural disasters, youth and sports and science.

\section{Commercial and Industrial Development Sector}

In the early stages of Mexico's relationship with Saint Lucia, technical bilateral cooperation with Mexico was oriented towards the commercial and industrial development sector, primarily Arts and Craft. Through the National Fund for the Promotion of Craft (FONART) Mexico has collaborated with the Ministry of Commerce of Saint Lucia to ascertain the viability of the Art and Craft sector of Saint Lucia. Additionally, workshops were held in important 
areas such as basket making, soap, paper and textile production and the commercialization of said products. Many Saint Lucian Artisans and small business owners have benefitted significantly from this form of assistance.

\section{Contribution to Rehabilitation Post Christmas Eve Trough}

After the passage of a trough system on 24 $4^{\text {th }}$ December 2013 in Saint Lucia, which caused widespread damage to the island, the Government of Mexico generously contributed USD \$500 000 towards the rehabilitation efforts.

\section{Agriculture}

In 2013, through a triangular cooperation agreement with the Inter-American Institute for Cooperation on Agriculture (IICA) and the Government of Saint Lucia, the Government of Mexico donated two automated greenhouses for protected agriculture that are being used for experimentation and for training students. Additionally, in 2015 the Ministry of Agriculture received 5000 crops of coconut plants resistant to the lethal yellow disease from the Yucatan's Centre for Scientific Research in Mexico.

\section{Health Sector}

Saint Lucia's health sector stands to benefit from these Agreements as national efforts to modernise this sector continue. In June 2015, the Government of Mexico contributed USD \$2 657890.50 towards the completion of the Saint Jude's Hospital. The two buildings constructed with those resources, namely the morgue and the security and ambulance section, were handed over to the Government of Saint Lucia in November 2016 in the framework of the visit of H. E. Socorro Flores Liera, Vice Minister for Latin America and the Caribbean I the Ministry of Foreign Affairs of Mexico.

\section{Water Resources}

Furthermore, in March of 2015, the Government of Mexico contributed USD \$5 million towards the implementation and commissioning of the Dennery Water Supply Redevelopment Project. The purpose of the project is to provide the residents of Dennery with a reliable water supply. The 
project was officially launched on the $17^{\text {th }}$ of February with the sod turning, and the first phase of the project is expected to be completed by the end of this year.

\section{Honouring the Work of National Heroes}

Government of Mexico has been instrumental in recognising and honouring the work of our national heroes. In April 2012, in honour of the respective literary stalwarts of Mexico and Saint Lucia, Nobel Laureates, Octavio Paz and Honourable Derek Walcott were both inaugurated at the Octavio Paz-Derek Walcott Hall at the Mexican Embassy in Castries. Subsequently since 2015 the Embassy has participated with great success on the annual commemoration of Saint Lucia's Nobel Laureates.

\section{Education and Human Resource Development}

In the area of education, Saint Lucian nationals have benefitted from both undergraduate and post graduate scholarships offered to CARICOM nationals and funded by the Government of Mexico. This initiative aims to enhance the human resource of the Caribbean region as a whole. The awards are made available for study at Universities in Mexico. To date, several Saint Lucian nationals have successfully completed studies in Mexico under this programme, many of whom have since returned to make meaningful contributions to Saint Lucia's national development.

\section{Programmes Offered by the Government of Mexico (2012-2015)}

- $5^{\text {th }}$ Spanish Language Course for Foreign Diplomats $\left(2^{\text {nd }}\right.$ July $-5^{\text {th }}$ December 2012)

- Workshop on the Management of Vector Borne Diseases $\left(24^{\text {th }}-28^{\text {th }}\right.$ June 2013)

- Spanish Language and Diplomacy Immersion Courses for the Caribbean Community (CARICOM) ( $5^{\text {th }}$ August $-25^{\text {th }}$ November 2013) This course was offered in collaboration with the Government of Chile

- International Workshop on Natural Disasters Associated with Natural Phenomena $\left(25^{\text {th }}-27^{\text {th }}\right.$ November 2013)

- Spanish Language and Diplomacy Immersion Courses for the Ca- 
ribbean Community (CARICOM) Diplomats (20 $0^{\text {th }}$ January- $16^{\text {th }}$ May 2014) The course was held in collaboration with the Government of Chile.

- $20^{\text {th }}$ Mexican Foreign Policy Course for Diplomats $\left(24^{\text {th }}\right.$ September $-4^{\text {th }}$ October 2014)

- $21^{\text {st }}$ Mexican Foreign Policy Course for Diplomats (23 ${ }^{\text {rd }}$ September- $7^{\text {th }}$ October 2015)

\section{Conclusion}

The Government of Saint Lucia remains committed to its long-standing relationship with the Government of Mexico and will continue to further strengthen our diplomatic interaction which aims to mutually benefit both our nations and their citizens.

Ministry of Foreign Affairs

of Saint Lucia 